\title{
Character Education Practices at a Piloted Primary School
}

\author{
L. Indrayani, L. P. Artini, \& K. Seken \\ Universitas Pendidikan Ganesha \\ Singaraja, Indonesia \\ indrayaniluh@gmail.com
}

\begin{abstract}
Some theories in psychology explain the importance of shaping character since early and primary schools as they are the first formal education to cultivate positive values through handson activities. This study aimed at analyzing character education practices at a piloted primary school in Bali. This study was in the form of descriptive case study and the data were collected through documents analysis, observations, and interviews. The findings reveal that characters were not explicitly stated in most lesson plans, but they are detectable in integration with learning materials, strategies, and activities. However, the character education practices seemed ineffective since the focus scattered around the level of moral action and ignored moral knowledge and feeling. This means that students were mostly told about what to do with limited reasons and consequences of the values. It was also found that characters' assessment was very subjective in nature, since the method used was only an observation.
\end{abstract}

Keywords-character education practices

\section{INTRODUCTION}

The overwhelming negative behaviors demand a holistic approach to the education: knowledge, skill, character, and metacognition [4]. Therefore, the aim of today's education is not merely focused on acquiring knowledge, but also developing the character to benefit the knowledge [19]. In Indonesia, Curriculum 2013 has been developed focusing on three dimensions: attitude, knowledge, and skill [14]. In comparison to the previous curriculum, Curriculum 2013 gives a clearer indication of how the character values are to be planned, implemented, and assessed. According to Aisyah (2014), character is a habituation of the core values. In Indonesia, there are 18 core values to be incorporated in instructional process: religiousness, honesty, tolerance, discipline, hard working, creativity, independence, democracy, curiosity, patriotism, confidence, respect, fond of reading, peacefulness, care with social, care with the environment, and responsibility [14].

In addition to that, character education seems to be more prioritized in primary schools. This is in line with Pearson \& Nicholson (2000) for whom children develop a sense of right and wrong in early childhood. Adults, particularly teachers, are expected to be role models reflecting positive values within and beyond classroom activities [22]. Therefore, stakeholders must be hand in hand modeling positive values consistently and continuously (Arthur, 2003) because developing character must be done through a sustained process of teaching, example, learning, and practice [17].

Character education is very crucial to be introduced since early because it has a strong positive impact towards the students' development, academic success, and self-esteem [20]. In other words, it helps students to be academically and morally prepared [8]. Before conducting instructional process, it is a mandatory for every teacher to prepare a lesson plan as it is extremely useful to conduct an instructional and assessment process [7]. An adoption of values into lesson plans is needed either by adding or modifying learning steps, indicators, and assessment [15].

In order to motivate students to show positive behavior, they need to be provided with a number of activities: discussion, collaborative activities, experiential activities, role play, reading literature, storytelling, and inviting community experts [9]. Reading literature need to be given since early as it contains lots of moral values that help students to put themselves as the characters in the story [2,21]. Furthermore, games also help students to be part of a group, learn proper social manners and attitudes [11]. In other word, character education is a combination of direct teaching and involvement in community services [6]. It is in line with Lickona (2013) who states that character education practices must cover three essential domains: moral knowing, moral feeling, and moral action [10].

At the end of an instructional process, an authentic assessment needs to be conducted to know whether or not what has been designed and implemented successfully achieved the goal. Authentic assessment describes multiple forms of assessments (O'Malley \& Pierce, 1996) reflecting students' learning, achievement, motivation, and attitudes. It involves several methods, such as: observation, self-assessment, peerassessment, and journal [14].

Unfortunately, the implementation of character education through this new curriculum still raises lots of objections. Indonesian teachers tend to do plenty of activities focusing only on the cognitive aspect but ignore character development. As a result, character education has not been quite able to construct positive character for students [5].

Apart from the empirics on character education, this study attempted to investigate in-depth character education practices at a piloted primary school. The practices here refer to how the values were addressed in the lesson plan, how they were implemented in the instructional process, and how they were authentically assessed during instructional process. Finally, in- 
vestigation on obstacles on character values insertion into the lessons was also described.

\section{METHOD}

This research was designed in the form of descriptive case study research since it emphasizes on in-depth analysis of the unit under study (Yin, 2014) and describes the data as they occur [12]. The subjects of this research were a classroom teacher of Grade five who taught the thematic subject, an English teacher, and 32 students at the piloted Primary school. Both teachers had had special experience to participate in workshops related to the implementation of character-based instruction as required by Curriculum 2013.

The objects of this study were character-based lesson plans, character-based implementations, and character-based assessments. The methods in collecting the data were through documents studies, observations, and interviews. Those data were acquired by considering the researcher herself as the main instrument and was helped by some devices: interview guide and audio video recorder to gather the data.

Firstly, all documents regarding character values insertion: syllabus, lesson plans, teacher-student's agreement, teacher's book, and students' book were collected to be analyzed whether or not the components in the lesson plan have inserted character values. Those analyses were presented in the form a systematic description.

A structured observation was conducted involving two times observations in each Thematic and English class. A video recorder was used to record the whole instructional processes to know whether or not the teachers had integrated character values in their lesson. Observations sheets were also used to write down what was going on during the observation. The data from the observations: pictures, videos, and field note were analyzed by describing the findings related to character education practices. In addition, semi structured interviews were done since it was conducted formally with a list of questions to both teachers but some spontaneous questions might be arisen during the interview to dig more information.

The data were analyzed by using Miles and Huberman (1994) data analysis involving data collection, data reduction, data display, and conclusion. To avoid bias in the result of the study, methodological triangulation was used involving: document study, observations, and interviews to check the validity and the reliability of the data.

\section{RESULTS AND DISCUSSION}

Character values insertion in the lesson plans

The development of character-based lesson plans included some components, i.e. subject identity, core competency, basic competency, indicators, learning objectives, learning sources, learning materials, learning media, learning strategies, learning activities, and assessment. The character values were not ex- plicitly stated in most parts of the lesson plan, but they were integrated into learning materials, learning strategies, and learning activities. The learning materials were loaded with some values and there was character values reflection part at the end of the lesson to make the students aware of the values integrated throughout the lessons. The teachers planned to use several teaching strategies: discussion, role play, collaborative work, inquiry learning, presentation, and individual work. The learning activities were done in three major steps: preactivities, whilst-activities, and post-activities. Through the analysis of the activities in the lesson plans, 15 values were found to be integrated into learning materials and strategies in the lesson plans: religiousness, confidence, patriotism, responsibility, independence, love reading habit, creativity, hard working, communication, tolerance, curiosity, honesty, respect, discipline, and democracy. However, those values were not adopted in the basic competency, indicators, and objectives. These reveal that the teachers did not fully follow the policy of Ministry of National Education (2010) that moral value needs to be adopted in the lesson plan. It is a must to insert values into the lesson plan, otherwise, the expected competencies will not successfully achieve through the instructional activities [7].

Character values insertion in instructional process

The implementation of character values was done in several ways: role modeling as a mission of the school (Friendly Community School), teacher-students agreement, and teaching strategies. Friendly Community School is a government program to support character education practices. It rules how the teachers should positively behave in interacting within and beyond the classroom as it determines the success of character development and character building [3].

The instructional process involving three steps, i.e. preactivities, whilst-activities, and post-activities. It was found that before and after the instructional process, the students spontaneously prayed that has become a class culture. It was obviously seen that the character of being religious has been trained regularly. After praying, the teachers did brainstorming activities by picking out one question from a box containing plenty of questions related to all subjects. The picked question was read by the teacher as a means to brainstorm students' prior knowledge. It was admitted by the teachers that this activity aimed at stimulating students' curiosity and trained them to be communicative in expressing their thoughts. Afterward, the teachers periodically stated the teacher-students' agreement consisting of some school rules completed with some consequences.

In whilst-activities, the teachers employed scientific approach steps: observing, questioning, exploring, associating, and communicating and employed several learning strategies: collaborative work, individual work, role-play, presentation, and inquiry learning. However, its implementation seemed ineffective since the teachers were very likely to jump over mor- 
al action, and ignore moral knowing and moral feeling as advised by [10].

Post-activities were done by reviewing and reflecting the instructional process by involving the students. From the overall instructional process done in the classroom, it was found that there were 13 values tried to be introduced to the students, i.e. religiousness, confidence, responsibility, independence, love reading habit, hard working, communication, tolerance, curiosity, honesty, respect, discipline, and democracy regardless of its implementation that still need to be improved.

\section{Assessment of character-values}

The assessment method used by the teachers seemed to be very subjective since the assessment only done through observation. There were 12-character values assessed by the teachers, i.e. religiousness, confidence, patriotism, responsibility, independence, love reading habit, creativity, hardworking, communication, tolerance, curiosity, and honesty. However, the character values assessed were not relevant with the characters stated in the core competency.

According to Ministry of Education and Culture (2013), there are several ways to measure students' attitude, authentically i.e. through observation, self-assessment, peerassessment, and journal. Authentic assessment is important as it describes students' competencies through different perspectives [16].

After analyzing the lesson plan, the implementation, and the assessment of character-based instruction, it is important to present the summary of the findings in the form of tables to see the consistency of the teachers in implementing character values seen from the lesson plans coded as 'LP'; the implementation coded as ' $\mathrm{I}$ '; and the assessment coded as ' $\mathrm{A}$ ' as presented in Table 1 as follows.

\section{TABLE I. SUMMARY OF CHARACTERS INSERTED}

\begin{tabular}{|c|l|l|l|l|}
\hline No & \multicolumn{1}{|c|}{ Core Values } & \multicolumn{1}{c|}{ LP } & \multicolumn{1}{c|}{ I } & \multicolumn{1}{c|}{ A } \\
\hline 1. & Religious & $\checkmark$ & $\checkmark$ & $\checkmark$ \\
\hline 2. & Confident & $\checkmark$ & $\checkmark$ & $\checkmark$ \\
\hline 3. & Patriotic & $\checkmark$ & - & $\checkmark$ \\
\hline 4. & Responsible & $\checkmark$ & $\checkmark$ & $\checkmark$ \\
\hline 5. & Independent & $\checkmark$ & $\checkmark$ & $\checkmark$ \\
\hline 6. & Love reading & $\checkmark$ & $\checkmark$ & $\checkmark$ \\
\hline 7. & Creative & $\checkmark$ & - & $\checkmark$ \\
\hline 8. & Hard working & $\checkmark$ & $\checkmark$ & $\checkmark$ \\
\hline 9. & Communicative & $\checkmark$ & $\checkmark$ & $\checkmark$ \\
\hline 10. & Tolerant & $\checkmark$ & $\checkmark$ & $\checkmark$ \\
\hline 11. & Curious & $\checkmark$ & $\checkmark$ & $\checkmark$ \\
\hline 12. & Honest & $\checkmark$ & $\checkmark$ & $\checkmark$ \\
\hline 13. & Respectful & $\checkmark$ & $\checkmark$ & - \\
\hline 14. & Disciplined & $\checkmark$ & $\checkmark$ & - \\
\hline 15. & Democratic & $\checkmark$ & $\checkmark$ & - \\
\hline 16. & Peaceful & - & - & - \\
\hline
\end{tabular}

\begin{tabular}{|c|l|l|l|l|}
\hline 17. & Care with social & - & - & - \\
\hline 18. & Care with environment & - & - & - \\
\hline
\end{tabular}

The data revealed that there was inconsistency on the part of the teachers in terms of designing values in the lesson plan, implementing it in the instructional process, and its assessment. This means that the teachers were still confused in infusing their lesson with character values.

Obstacles encountered by the teachers

There were a number of obstacles found as follows: the character values were not addressed in most of the lesson plan components, the values were not effectively integrated in a systematic way through moral feeling, moral knowing, and moral action, and the values were not assessed authentically. These problems arose during interview. There were some sources of problems as perceived by the teachers, such as: lack of experience, lack of models and supervision in character education practices.

\section{CONCLUSION}

Character education practices in piloted primary school seemed to be ineffective since there was inconsistency between the values designed, implemented, and assessed. The values were not adopted in most components of the lesson plan, i.e. basic competency, indicator, learning objective, and learning media. The practice of the character-based instruction was done by considering the program of Friendly Community School, periodically reminding the students about the teacherstudents agreement, and employing learning strategies. However, the teachers did not know how to employ the learning activities and learning strategies to effectively boost the students' character. The assessment of the character values was not authentic since it only used an observation. The teachers were still having problems in incorporating character values into their lessons. It was due to lack of competence and clear guidelines regarding character education practices.

\section{REFERENCES}

[1] A.R. Aisyah, "The implementation of character educa-tion through contextual teaching and learning at personality development unit in the sriwijaya university palembang," International Journal of Education and Research, vol. 2, no. 10, 2014.

[2] G.M. Almerico, "Building character through literacy with children's literature," Research in Higher Education Journal, vol. 26, pp. 1-13, 2014.

[3] J. Arthur, "Character education in british education policy," Journal of Research in Character Education, vol. 1, no. 1, pp. 43-58, 2003.

[4] Center for Curriculum Redesign. Character education for the $21 \mathrm{st}$ century, viewed May 1st 2017 http://curriculumredesign.org, 2015.

[5] A. Hidayati, M. Zaim, K. Rukun and Darmansyah, "The development of character education curriculum for elemen-tary student in west sumatera," International Journal of Edu-cation and Research, vol. 2, no. 6, 2014. 
[6] K. Hyungsook, "Socially engaged art practice and char-acter education: understanding others through visual art," International Journal of Education through Art, vol. 10, no. 1, pp. 55-69, 2014.

[7] L. Jensen, "Planning lessons. in M. Celce-Murcia (Ed)," Teaching English as a Second or Foreign Language (3rd edition, pp. 403-413). Heinle \& Heinle, Boston, 2001.

[8] S.A. Kamaruddin, "Character education and students social behavior," Journal of Education and Learning, vol. 6, no. 4, pp. 223-230, 2012.

[9] T. Likona, "Eleven principles of effective character education," The Journal of Moral Education, vol. 25, no. 1, pp. 93-100, 1996.

[10] T. Lickona, Pendidikan karakter: panduan lengkap menididk siswa menjadi pintar dan baik, Bandung: Nusa Media, 2013.

[11] W.S. Mak, "Evaluation of a moral and character educa-tion group for primary school students," Discovery - SS Stu-dent E-journal, pp. 142164, 2014.

[12] J. McDonough and S. McDonough, Research methods for english language teachers, Arnold: London, 1997.

[13] M.B. Miles and A.M. Huberman, Qualitative data analy-sis, Thousand Oaks, Sage, 1994.

[14] Ministry of Education and Culture, Modul kurikulum 2013, 2013.

[15] Ministry of National Education, Buku panduan pen-didikan karakter smp, Jakarta: Badan Penelitian dan Pengem-bangan Pusat Kurikulum, 2010.

[16] J.M. O'Malley and Pierce, Authentic assessment for english language learners, Addison-Wesley: USA, 1996.

[17] A. Pala, "The need for character education," International Journal of Social Sciences and Humanity Studies, vol. 3, no. 2, pp. 23-32, 2011.

[18] Q.M. Pearson and J.I. Nicholson, "Comprehensive char-acter education in the elementary school: Strategies for ad-ministrators, teachers, and counselors" Journal of Humanistic Counseling, Education and Development, vol. 38, no. 243, 2000.

[19] D.L. Shield, Character as the Aim of Education, viewed Many 1st 2017 <Kappan Magazine.org>, 2011.

[20] A. Tannir and A. Al-Hroub, "Effects of character educa-tion on the selfesteem of intellectually able and less able elementary students in kuwait," International journal of special education, vol. 28 , no. 1 , 2013.

[21] E.T. Widyahening and N.E. Wardhani. "Literary works and character education," International Journal of Language and Literature, vol. 4, no. $1,2016$.

[22] K. Yildirim, "Values education experiences of turkish class teachers: a phenomenological approach," Eurasian Journal of Educational Research, vol. 35, pp. 165-184, 2009.

[23] R. Yin, Case study research: design and methods, 5th edition. Sage, Los Angeles, 2014. 